\title{
SHARP BOUNDS FOR THE NEUMAN-SÁNDOR MEAN IN TERMS OF GENERALIZED LOGARITHMIC MEAN
}

\author{
Yong-Min Li, Bo-Yong Long AND Yu-Ming CHU
}

Abstract. In this paper, we find the largest value $\alpha$ and least value $\beta$ such that the double inequality $L_{\alpha}(a, b)<M(a, b)<L_{\beta}(a, b)$ holds for all $a, b>0$ with $a \neq b$. Here, $M(a, b)$ and $L_{p}(a, b)$ are the Neuman-Sándor and $p$-th generalized logarithmic means of $a$ and $b$, respectively.

Mathematics subject classification (2010): 26E60.

Keywords and phrases: Neuman-Sándor mean, generalized logarithmic mean, power mean, Seiffert mean.

\section{REFERENCES}

[1] K. B. Stolarsky, Generalizations of the logarithmic mean, Math. Mag. 48 (1975), 87-92.

[2] E. Neuman And J. SÁndor, On the Schwab-Borchardt mean, Math. Pannon. 14, 2 (2003), 253-266.

[3] M. K. WANG, Z. K. WANG AND Y. M. CHU, An optimal double inequality between geometric and identric means, Appl. Math. Lett. 25, 3 (2012), 471-475.

[4] Y. M. CHU, M. K. WANG AND S. L. QIU, Optimal combinations bounds of root-square and arithmetic means for Toader mean, Proc. Indian Acad. Sci. Math. Sci. 122, 1 (2012), 41-51.

[5] Y. M. ChU, M. K. WANG AND Z. K. WANG, An optimal double inequality between Seiffert and geometric means, J. Appl. Math. 2011, Article ID 261237, 6 pages.

[6] Y. M. ChU, S. W. Hou AND W. M. GonG, Inequalities between logarithmic, harmonic, arithmetic and centroidal means, J. Math. Anal. 2, 2 (2011), 1-5.

[7] Y. M. CHU, M. K. WANG AND Z. K. WANG, A best-possible double inequality between Seiffert and harmonic means, J. Inequal. Appl., 2011 (2011): 94.

[8] Y. M. ChU AND M. K. WANG, Optimal inequalities between harmonic, geometric, logarithmic, and arithmetic-geometric means, J. Appl. Math. 2011, Article ID 618929, 9 pages.

[9] Y. M. ChU, M. K. WANG AND Z. K. WANG, A sharp double inequality between harmonic and identric means, Abstr. Appl. Anal. 2011, Article ID 657935, 7 pages.

[10] Y. M. ChU, M. K. WANG AND W. M. Gong, Two sharp double inequalities for Seiffert mean, J. Inequal. Appl. 2011 (2011), 44.

[11] Y. M. ChU, S. S. WANG AND C. Zong, Optimal lower power mean bound for the convex combination of harmonic and logarithmic means, Abstr. Appl. Anal. 2011, Article ID 520648, 9 pages.

[12] Y. M. Chu, C. Zong AND G. D. WANG, Optimal convex combination bounds of Seiffert and geometric means for the arithmetic mean, J. Math. Inequal. 5, 3 (2011), 429-434.

[13] Y. M. Chu AND B. Y. Long, Sharp inequalities between means, Math. Inequal. Appl. 14, 3 (2011), 647-655.

[14] Y. F. QIU, M. K. WANG, Y. M. ChU AND G. D. WANG, Two sharp inequalities for Lehmer mean, identric mean and logarithmic mean, J. Math. Inequal. 5, 3 (2011), 301-306.

[15] M. Y. ShI, Y. M. ChU AND Y. P. JiAnG, Optimal inequalities related to the power, harmonic and identric means, Acta Math. Sci. 31A, 5 (2011), 1377-1384.

[16] Y. M. CHU AND W. F. XIA, Two optimal double inequalities between power mean and logarithmic mean, Comput. Math. Appl. 60, 1 (2010), 83-89. 
[17] W. F. XIA, Y. M. ChU AND G. D. WANG, The optimal upper and lower power mean bounds for a convex combination of the arithmetic and logarithmic means, Abstr. Appl. Anal. 2010, Article ID 604804, 9 pages.

[18] M. K. WANG, Y. M. ChU AND Y. F. QIU, Some comparison inequalities for generalized Muirhead and identric means, J. Inequal. Appl. 2010, Article ID 295620, 10 pages.

[19] M. Y. SHI, Y. M. ChU AND Y. P. JiAng, Three best inequalities for means in two variables, Int. Math. Forum 5, 22 (2010), 1059-1066.

[20] W. F. XIA AND Y. M. CHU, Optimal inequalities related to the logarithmic, identric, arithmetic and harmonic means, Rev. Anal. Numér. Théor. Approx. 39, 2 (2010), 176-183.

[21] Y. M. CHU AND W. F. XIA, Inequalities for generalized logarithmic means, J. Inequal. Appl. 2009, Article ID 763252, 7 pages.

[22] M. Y. SHI, Y. M. CHU AND Y. P. JANG, Optimal inequalities among various means of two arguments, Abstr. Appl. Anal. 2009, Article ID 694394, 10 pages.

[23] H. N. SHI AND S. H. WU, Refinement of an inequality for the generalized logarithmic mean, Chinese Quart. J. Math. 23, 4 (2008), 594-599.

[24] F. QI, S. X. CHEN AND C. P. CHEN, Monotonicity of ratio between the generalized logarithmic means, Math. Inequal. Appl. 10, 3 (2007), 559-564.

[25] X. LI, C. P. Chen AND F. QI, Monotonicity result for generalized logarithmic means, Tamkang J. Math. 38, 2 (2007), 177-181.

[26] C. P. Chen And F. QI, Monotonicity properties for generalized logarithmic means, Aust. J. Math. Anal. Appl. 1, 2 (2004), Article 2, 4 pages.

[27] H. Alzer ANd S. L. QIU, Inequalities for means in two variables, Arch. Math. 80, 2 (2003), 201215.

[28] B. Mond, C. E. M. Pearce And J. PeČArić, The logarithmic mean is a mean, Math. Commun. 2, 1 (1997), 35-39.

[29] P. Kahlig And J. MatKows Ki, Functional equations involving the logarithmic mean, Z. Angew. Math. Mech. 76, 7 (1996), 385-390.

[30] C. E. M. PEARCE AND J. PeČARIĆ, Some theorems of Jensen type for generalized logarithmic means, Rev. Roumaine Math. Pures Appl. 40, 9/10 (1995), 789-795.

[31] A. O. Pittenger, The logarithmic mean in $n$ variables, Amer. Math. Monthly 92, 2 (1985), 99-104.

[32] K. B. Stolarsky, The power and generalized logarithmic means, Amer. Math. Monthly 87, 7 (1980), 545-548.

[33] T. P. LIN, The power mean and the logarithmic mean, Amer. Math. Monthly 81 (1974), 879-883.

[34] P. S. Bullen, D. S. Mitrinović And P. M. Vasić, Means and Their Inequalities, D. Reidel publishing Co., Dordrecht, 1988.

[35] A. O. Pittenger, Inequalities between arithmetic and logarithmic means, Univ. Beograd. Publ. Elektrotehn. Fak. Ser. Mat. Fiz. 678-715 (1980), 15-18.

[36] B. Y. LONG AND Y. M. ChU, Optimal inequalities for generalized logarithmic, arithmetic, and geometric means, J. Inequal. Appl. 2010, Article ID 806825, 10 pages.

[37] Y. M. CHU AND B. Y. Long, Best possible inequalities between generalized logarithmic mean and classical means, Abstr. Appl. Anal. 2010, Article ID 303286, 13 pages.

[38] E. Neuman And J. SÁndor, On the Schwab-Borchardt mean II, Math. Pannon. 17, 1 (2006), 49-59. 